\title{
REGIONALIZATION OF HURRICANE RAINFALL IN THE FORESTS, PROTECTED AND RESERVED ZONES OF MEXICO
}

\author{
Alfonso Gutierrez-Lopez ${ }^{1}$ \\ ${ }^{1}$ Autonomous University of Queretaro
}

October 29, 2020

\begin{abstract}
Hurricanes are extreme phenomena that affect the coasts of Mexico every year. The economic and biodiversity losses caused by these extreme events are extensive. However, little is known about the effects that these severe weather incidents have on Mexico's forest conservation and protected areas. A hydrological characterization and regionalization of the storms caused by the rain fields generated by all the hurricanes that touched the Mexican coast from 1966 to 2017 were carried out. Adimensional Huff Curves are proposed to get precipitation hyetograms from which the erosion factor of a storm is obtained; using the Universal Soil Loss Method (USLE). The results made it possible to get the typical precipitation hyetograms in the forests and protected areas, before, during, and after the impact of a hurricane. The proposed hydrological regionalization made it possible to estimate the rainfall intensity in 30 minutes to characterize the start of rain erosion. The method proposed in this research was applied in the 177 Natural Protected Areas (25628239 ha), as well as in the 370 voluntarily designated areas for Conservation (399643 ha), in Mexico. It is concluded that, with the regionalization and the proposed equations, it is possible to get typical hurricane precipitation hyetograms, which would allow us to detail the forest management plans in forests, ecological reserves, and protected areas of Mexico.
\end{abstract}

\section{Hosted file}

Land_Degradation_\&_Development_Paper_\#8_version_3.7_(Giselle).pdf available at https: //authorea.com/users/371186/articles/489604-regionalization-of-hurricane-rainfall-inthe-forests-protected-and-reserved-zones-of-mexico

\section{Hosted file}

Figures.pdf available at https://authorea.com/users/371186/articles/489604-regionalizationof-hurricane-rainfall-in-the-forests-protected-and-reserved-zones-of-mexico

\section{Hosted file}

Tables.pdf available at https://authorea.com/users/371186/articles/489604-regionalization-ofhurricane-rainfall-in-the-forests-protected-and-reserved-zones-of-mexico

\section{Hosted file}

Anexo A.pdf available at https://authorea.com/users/371186/articles/489604-regionalizationof-hurricane-rainfall-in-the-forests-protected-and-reserved-zones-of-mexico 